\title{
Comparison of Field, Greenhouse, and Detached-Leaflet Evaluations of Tomato Germ Plasm for Early Blight Resistance
}

\author{
M. R. Foolad and N. Ntahimpera, Department of Horticulture, B. J. Christ, Department of Plant Pathology, and \\ G. Y. Lin, Department of Horticulture, Pennsylvania State University, University Park 16802
}

\begin{abstract}
Foolad, M. R., Ntahimpera, N., Christ, B. J., and Lin, G. Y. 2000. Comparison of field, greenhouse, and detached-leaflet evaluations of tomato germ plasm for early blight resistance. Plant Dis. 84:967-972.

Twenty-nine tomato genotypes (cultivars, breeding lines, and plant introductions), representing three Lycopersicon species, were evaluated for resistance to early blight (EB) caused by the fungus Alternaria solani. Evaluations were conducted in replicated trials in multiple years under field and greenhouse conditions (with whole plants) and in growth chamber (with detached leaflets). In the field experiments, plants were evaluated for disease symptoms, and area under the disease progress curve (AUDPC) and final percent defoliation were determined. In the greenhouse experiments, plants were evaluated for percent defoliation following spray-inoculation with isolates of $A$. solani. In the growth chamber experiments, lesion radius, rate of lesion expansion, and final disease severity were determined for individual detached leaflets inoculated with isolates of $A$. solani. There were significant differences among genotypes in their response to A. solani infection in the field, greenhouse, and growth chamber experiments. In the field and greenhouse experiments, disease response varied from near-complete resistance in some accessions of the wild tomato species L. hirsutum (e.g., PI126445 and LA2099) to complete susceptibility in tomato cultivar New Yorker and breeding line NC84173. The previously developed EB-resistant breeding lines 88B231, 89B21, C1943, NCEBR-1, NCEBR-2, NCEBR5, NCEBR-6, NC24E, and NC39E exhibited more resistance than New Yorker and NC84173. Field and greenhouse results were comparable across replications and years, and there were great correspondences $(r \approx 0.71, P<0.01)$ between field and greenhouse resistance across genotypes. In contrast, results from the detached-leaflet assays were inconsistent across experiments and not correlated with either greenhouse or field results. The overall results indicate the utility of greenhouse evaluation and the inadequacy of detached-leaflet assay for screening tomatoes for $\mathrm{EB}$ resistance.
\end{abstract}

Additional keywords: disease resistance, Lycopersicon esculentum, L. hirsutum, L. pimpinellifolium

Early blight (EB), caused by Alternaria solani (Ellis \& Martin) Jones \& Grout, is one of the most common and destructive diseases of tomato, Lycopersicon esculentum Mill., in areas of heavy dew, rainfall, and high relative humidity $(3,27)$. EB is also important in semiarid areas when nightly dew is sufficiently frequent to allow disease development (31). In the United States, the disease can be severe in the midwestern, eastern, and northeastern regions. The fungus can cause disease on foliage (leaf blight), stem (collar rot), and fruit, and can result in severe damage during all stages of plant development $(3,5,27)$. The leaf blight phase, commonly referred to as early blight, is the most im-

Corresponding author: M. R. Foolad

E-mail: mrf5@psu.edu

Accepted for publication 26 May 2000.

Publication no. D-2000-0626-01R

(c) 2000 The American Phytopathological Society extended fungicide spray interval and have contributed to a significant reduction in chemical inputs for EB control in tomato $(13,15)$. However, many of the resistant lines are late maturing or the level of resistance is less than sufficient under most EB epidemic field conditions (23). Thus, breeders are still seeking tomato cultivars with higher levels of resistance to EB and with earlier maturity.

Breeding for disease resistance requires efficient screening techniques, genetic resources for resistance, knowledge of genetic and physiological mechanisms underlying resistance, and appropriate breeding strategies to transfer resistance genes into improved genetic backgrounds. Compared with many other diseases of tomato, limited progress has been made to improve EB resistance of tomato cultivars. Major difficulties in the past breeding efforts have been with the screening of plants for resistance and transferring of resistance genes across genotypes (25). EB is associated with the physiological maturity of the plant; older leaves are more susceptible than younger leaves, and a heavy fruit set enhances the disease $(3,6,23,25,27)$. Furthermore, plants with late maturity, indeterminate growth habit, or low yielding ability appear to be more resistant $(3,5,23)$. Resistance has been characterized as horizontal, controlled by polygenes, and highly affected by environmental conditions $(5,6,26,28)$.

Various techniques have been employed for screening tomato plants for EB resistance. Field screening has been a routine procedure $(3-5,12,19,22,25,27,28,32)$. It is, however, slow, time-consuming, and highly affected by uncontrollable environmental conditions such as temperature, humidity, and simultaneous presence of other pathogens. Greenhouse screening of tomato plants for EB resistance has been used with variable results (1$3,14,24,27,29)$. For instance, when lines with moderate levels of resistance were compared with susceptible lines, symptoms were not sufficiently different in most greenhouse tests to discriminate among lines $(2,27)$. Other studies, using $F_{1}$ and segregating backcross progeny of the cross between resistant $L$. hirsutum accession PI126445 and susceptible L. esculentum lines, indicated the effectiveness of greenhouse screening (12). The success of greenhouse screening depends, among other things, on the seedling age, plant 
resistance level, inoculum quality and quantity, inoculation technique, and preand postinoculation environmental conditions of the greenhouse. Growth chamber evaluation, using detached leaflets, has been extensively used for disease screening with obligate parasites, and to a lesser extent with facultative parasites $(16,20,35)$. In tomato, detached-leaflet assay was first employed by Douglas in 1922 (11) to compare the response of tomato varieties to inoculation with an undetermined species of Alternaria. Later, the use of this assay for comparing the virulence of different strains of $A$. solani and for evaluating the resistance of tomato genotypes was reported to be either ineffective (34) or effective (20). If proven useful, both greenhouse evaluation and detached-leaflet assay can facilitate rapid germ plasm screening and developing tomatoes with enhanced EB resistance.

No formal comparison had been made between the effectiveness of field, greenhouse (GH), and detached-leaflet (DL) assays for screening tomatoes for EB resistance. Therefore, a major goal of this research was to conduct such a comparison, using tomato germ plasm from different species and with different resistance levels. We also were interested in examining the EB resistance of some tomato cultivars, breeding lines, and accessions with previously known or unknown resistance under our conditions.

\section{MATERIALS AND METHODS}

Plant material. Twenty-nine tomato genotypes, including susceptible cultivar New Yorker and breeding line NC84173, several cultivars and breeding lines with known or unknown resistance to EB, several accessions (plant introductions) of the wild tomato species Lycopersicon hirsutum Humb. \& Bonpl. and L. pimpinellifolium (Jusl.) Mill., and an accession of L. esculentum var. cerasiforme Mill. (cherry tomato), were used in this study (Table 1). Original seeds were provided by USDA Plant Genetic Resources Unit, Geneva, NY (PI numbers), CM Rick Tomato Genetics Resource Center, University of California, Davis (LA numbers, UCT5, and Edkawy), and R. G. Gardner, North Carolina State University, Fletcher (NC numbers and resistant breeding lines 88B231, 89B21, and C1943). Large quantities of seed were produced by growing and self-pollinating (or sib-mating) plants in a field at the Penn State Research Farm, Rock Springs, PA.
Due to the presence of self-incompatibility, each accession of $L$. hirsutum was manually pollinated with bulked pollen from 10 sibling plants of the same accession.

Inoculum preparation. Two isolates of the fungus $A$. solani (126 and 134), previously obtained from naturally infected tomato plants in Pennsylvania, were used in this study. The cultures were grown on V8 agar medium (17.7\% V8 juice, $0.3 \%$ $\mathrm{CaCO}_{3}, 2 \%$ agar) in 9 -cm petri plates and incubated at 21 to $23^{\circ} \mathrm{C}$ under a cool-white fluorescent diurnal light with a 12 -h photoperiod. After 10 to 14 days, conidia were collected by flooding the plates with $\mathrm{ddH}_{2} \mathrm{O}$ (containing $0.01 \%$ Tween 20) and brushing the agar surface with a paintbrush. The spore density in the suspension was counted using a hemacytometer and varied between 20,000 and 50,000 conidia per $\mathrm{ml}$ in different experiments.

Disease screening. Field experiments. Experiments were conducted in three consecutive years (1996 to 1998) at the Penn State Research Farm. In each year, 6-weekold seedlings were planted in a randomized complete block design (RCBD) with three (in 1997) or four (1996 and 1998) replications. Each replicate contained a 10-plant single-row plot of each genotype. A row $\times$

Table 1. Early blight disease rating of tomato germ plasm under field conditions in 3 years at Rock Springs, PA

\begin{tabular}{|c|c|c|c|c|c|c|c|c|}
\hline \multirow[b]{2}{*}{ Genotype } & \multirow[b]{2}{*}{$\begin{array}{c}\text { Lycopersicon } \\
\text { species }\end{array}$} & \multirow[b]{2}{*}{$\begin{array}{c}\text { Growth } \\
\text { habit }^{x}\end{array}$} & \multicolumn{2}{|c|}{1996} & \multicolumn{2}{|c|}{1997} & \multicolumn{2}{|c|}{1998} \\
\hline & & & $\begin{array}{c}\text { Defoliation } \\
(\%)^{\mathrm{y}}\end{array}$ & $\mathbf{A U D P C}^{\mathbf{z}}$ & $\begin{array}{c}\text { Defoliation } \\
(\%)^{\mathrm{y}}\end{array}$ & AUDPC & $\begin{array}{l}\text { Defoliation } \\
(\%)^{\mathrm{y}}\end{array}$ & AUDPC \\
\hline New Yorker & L. esculentum & $\mathrm{D}$ & 100 & 3,295 & 68 & 427 & 100 & 2,120 \\
\hline NC84173 & L. esculentum & $\mathrm{D}$ & 100 & 3,102 & 33 & 207 & 90 & 1,679 \\
\hline UCT5 & L. esculentum & $\mathrm{D}$ & 99 & 2,649 & 13 & 76 & 78 & 1,274 \\
\hline Edkawy & L. esculentum & I & 99 & 2,659 & 17 & 96 & 83 & 1,503 \\
\hline PI120256 & L. esculentum & I & 92 & 2,339 & 15 & 96 & 81 & 1,350 \\
\hline PI174263 & L. esculentum & I & 92 & 2,406 & 13 & 80 & 73 & 1,248 \\
\hline Hawaii 7998 & L. esculentum & I & 96 & 2,236 & 15 & 96 & 60 & 733 \\
\hline $88 \mathrm{~B} 231$ & L. esculentum & $\mathrm{D}$ & 100 & 2,977 & 10 & 59 & 90 & 1,314 \\
\hline 89B21 (71B2) & L. esculentum & $\mathrm{D}$ & 100 & 2,788 & 7 & 43 & 89 & 1,664 \\
\hline C1943 & L. esculentum & $\mathrm{D}$ & 100 & 2,455 & 15 & 92 & 48 & 539 \\
\hline NCEBR-1 & L. esculentum & $\mathrm{D}$ & 99 & 2,536 & 8 & 56 & 53 & 769 \\
\hline NCEBR-2 & L. esculentum & $\mathrm{D}$ & 100 & 2,778 & 15 & 89 & 61 & 819 \\
\hline NCEBR-5 & L. esculentum & $\mathrm{D}$ & - & - & 8 & 49 & 73 & 1,031 \\
\hline NCEBR-6 & L. esculentum & $\mathrm{D}$ & - & - & 12 & 77 & 99 & 1,470 \\
\hline NC24E & L. esculentum & $\mathrm{D}$ & - & - & 4 & 20 & 26 & 235 \\
\hline NC39E & L. esculentum & $\mathrm{D}$ & - & - & 8 & 49 & 28 & 449 \\
\hline LA386 & L. hirsutum & I & 1 & 27 & 0 & 3 & 7 & 54 \\
\hline LA407 & L. hirsutum & I & 3 & 100 & 1 & 5 & 12 & 191 \\
\hline LA1033 & L. hirsutum & I & 1 & 27 & 0 & 3 & 12 & 172 \\
\hline LA1363 & L. hirsutum & I & - & - & 1 & 8 & 16 & 178 \\
\hline LA1393 & L. hirsutum & I & - & - & 1 & 5 & 8 & 56 \\
\hline LA1777 & L. hirsutum & I & 4 & 120 & 1 & 8 & 8 & 58 \\
\hline LA2099 & L. hirsutum & I & 3 & 86 & 0 & 3 & 8 & 68 \\
\hline PI126445 & L. hirsutum & I & 1 & 27 & 1 & 8 & 6 & 27 \\
\hline PI390513 & L. hirsutum & I & - & - & - & - & 6 & 21 \\
\hline PI390661 & L. hirsutum & I & - & - & - & - & 6 & 64 \\
\hline PI390662 & L. hirsutum & I & 1 & 27 & 1 & 5 & 8 & 73 \\
\hline LA722 & L. pimpinellifolium & I & 73 & 1,861 & 13 & 87 & 76 & 1,460 \\
\hline LA 1310 & $\begin{array}{c}\text { L. esculentum } \\
\text { (var. cerasiforme) }\end{array}$ & I & 85 & 2,222 & 10 & 63 & 48 & 744 \\
\hline Mean & & & 64 & 1,748 & 11 & 67 & 47 & 737 \\
\hline LSD (0.05) & & & 8 & 300 & 5 & 33 & 10 & 360 \\
\hline
\end{tabular}

${ }^{\mathrm{x}} \mathrm{D}=$ determinate, $\mathrm{I}=$ indeterminate.

${ }^{\mathrm{y}}$ Final percentage defoliation.

${ }^{\mathrm{z}} \mathrm{AUDPC}=\sum_{i=1}^{n}\left[\left(R_{i+1}+R_{i}\right) / 2\right]\left[t_{i+1}-t_{i}\right]$, where $R=$ rating (estimated proportion defoliated tissue) at the $i$ th observation, $t_{i}=$ time (days) since previous rating at the $i$ th observation, and $n=$ total number of observations). Each value is the average of three to four ratings per plot over three to four replicates and three to four rating dates. 
plant spacing of $1.5 \mathrm{~m} \times 0.75 \mathrm{~m}$ was used. The field sites were specifically chosen for their proximity to natural sources of inoculum of A. solani. However, to ensure a uniform source of the fungus, plants of susceptible New Yorker and NC84173 were planted at each end of treatment plots and spray-inoculated (R\&D Sprayers Inc., Opelousas, LA) with spore suspension mixtures of the two A. solani isolates in early August. Plants were fertigated using commercial recommendations for tomato (18). No fungicide was applied throughout the season. Plants were inspected for EB symptoms starting around mid-August for a total of four (1996), two (1997), or five times (1998) at approximately 10-day intervals (dry conditions in 1997 resulted in a reduced number of evaluation). At each evaluation, plants were visually rated for percent defoliation using a modified Horsfall-Barratt rating scheme (17), with 0 indicating no visible symptom of $\mathrm{EB}$ infection and 100 indicating complete defoliation. When no defoliation occurred, the rating was based upon an estimate of the necrotic area of the leaves. A single rating was assigned to each plot at each evaluation. The final rating was considered the final percent defoliation.

Greenhouse experiments. Four-week-old seedlings of the 29 genotypes were individually transplanted into half-gallon pots and grown in two separate sections of a greenhouse $(\mathrm{GH})$. Each section was used for evaluating plants for resistance to one of the two isolates of $A$. solani. In each section, plants were arranged in an RCBD with five blocks, each block including four plants of each genotype. Four blocks were used as treatment blocks (inoculated with A. solani) and one as the control block (not inoculated). Plants were grown under day/night temperatures of $23 / 18^{\circ} \mathrm{C}$, with a 12-h photoperiod and a light intensity of $400 \mu \mathrm{E} \cdot \mathrm{s}^{-1} \cdot \mathrm{m}^{-2}$ using high-pressure sodium lamps. During the late-seedling stage (6 to 7 weeks old), plants were individually spray-inoculated (R\&D Sprayers Inc., Opelousas, LA) with one isolate of $A$. solani. Following inoculation, plants were maintained in dark for $24 \mathrm{~h}$ at a relative humidity $(\mathrm{RH})$ of $>95 \%$. After that, $\mathrm{RH}$ was reduced to $\sim 85 \%$, and plants were maintained under a 12 -h photoperiod. The $\mathrm{RH}$, light, and temperature were controlled by a computer-regulated system. Six days after inoculation, plants were individually evaluated for disease symptoms. For each plant, the percentage of leaf area covered by EB lesions (or percent defoliated) was visually estimated at three plant sections (top, middle, and bottom). Percent defoliation for each plant was calculated as the average value for the three sections. For each isolate, $\mathrm{GH}$ experiments were repeated once.

Growth chamber experiment using detached leaflets. Fully expanded, young leaflets of greenhouse-grown plants were detached and placed on elevated polyhardware plastic mesh screen (Tensar Polytechnologies, Inc., Morrow, GA) fitted in moist chambers. Each chamber was a 10$\mathrm{cm}$-diameter $\times 4.5$-cm-deep clear plastic tub with a lid (Amoco, Naperville, IL) that accommodated two leaflets from one plant. To each chamber, $15 \mathrm{ml}$ of $\mathrm{ddH}_{2} \mathrm{O}$ was added to provide a water source for the leaflets and to maintain high $\mathrm{RH}$ inside the chamber. Leaflets were laid down on the screen such that the pedicels were inserted into the water. A 50- $\mu$ l droplet of spore suspension (containing ca. 2,000 conidia) was deposited on the upper surface of each leaflet with a micropipetter. The inoculated leaflets were incubated in the dark for $24 \mathrm{~h}$ at $\sim 22^{\circ} \mathrm{C}$, then maintained under coolwhite fluorescent diurnal light with a 12-h photoperiod. Starting on day 4 , lesion size (length and width on perpendicular directions) on each leaflet was measured daily for 3 to 5 days. Final radius of each lesion was calculated as one-half of the mean of the two perpendicular diameters. On the last day of evaluation, a final disease severity (percentage of leaflet area covered by the disease) was visually estimated for each leaflet. The experiment was carried out four times (four runs) for isolate 126 and three times for isolate 134 .

Data analysis. For the field experiments, area under the disease progress curve (AUDPC) was calculated for each genotype in each replication and year. The AUDPC and percent defoliation values were subjected to analysis of variance (ANOVA) using the PROC GLM procedure of the SAS software package (SAS Users Guide, SAS Institute, Cary, NC). Mean comparisons were conducted using Fisher's protected least significant difference (LSD) test (33). Pearson's correlation coefficients for different variables were computed using the PROC CORR command of the SAS program.

For the GH experiments, ANOVA was conducted on percent defoliation data using the PROC GLM procedure of the SAS program. Mean comparisons and correlation coefficient computations were conducted as described above. For the growth chamber experiments, a linear regression of lesion radius on time was used to determine the rate of lesion expansion (mm/day) for each genotype. For each isolate, each run was considered as one replication in time, and data from all runs (three or four) were pooled and analyzed as RCBD with blocks in time.

\section{RESULTS}

Field experiments. Field 1996. There were significant $(P<0.01)$ differences among genotypes in percent defoliation and AUDPC (Table 1). All of the L. hirsutum accessions exhibited nearly complete resistance to EB. In contrast, all of the $L$. esculentum genotypes, including accessions PI120256 and PI174263 and resistant lines 88B231, 89B21, C1943, NCEBR-1, and NCEBR-2, reached nearly complete defoliation by the end of the growing season (Table 1). The most susceptible genotypes were New Yorker and NC84173. The L. pimpinellifolium accession LA722 and L. esculentum var. cerasiforme accession LA1310 exhibited more resistance than the L. esculentum genotypes. There was a significant correlation $(r=0.99, P<0.01)$ between final percent defoliation and AUDPC (Table 2).

Field 1997. Because of dry conditions, there was less disease epidemic in 1997 than in 1996, and as a result, the percent defoliation and AUDPC values were much smaller (Table 1). However, there were significant $(P<0.01)$ differences among genotypes in percent defoliation and AUDPC. Similar to 1996, New Yorker and NC84173 were the most susceptible and $L$. hirsutum accessions the most resistant genotypes. There was a significant correlation $(r=0.99, P<0.01)$ between final percent defoliation and AUDPC (Table 2).

Field 1998. There were significant $(P<$ 0.01 ) differences among genotypes in percent defoliation and AUDPC (Table 1). The ranking of the genotypes was generally similar to that observed in 1996, with L. hirsutum accessions exhibiting the highest resistance ( $\leq 16 \%$ defoliation) and New Yorker, NC84173, and NCEBR-6 showing the least resistance ( $\geq 90 \%$ defoliation). The resistant breeding lines C1943, NCEBR-1, NCEBR-2, NCEBR-5, NC24E, and NC39E exhibited more resistance than New Yorker and NC84173, with percent defoliation ranging from 26 to $73 \%$ (Table 1). Among the resistant lines, NC24E and NC39E were the most resistant, with percent defoliation of 26 and 28\%, respectively. These two lines, however, were late maturing. There was a significant correlation $(r=0.98, P<0.01)$ between final percent defoliation and AUDPC (Table 2).

Relationships among field experiments in different years. Although rainfall and $\mathrm{RH}$ and, as a result, percent defoliation were different in different years, with the highest percent defoliation in 1996 and the lowest in 1997, there were good agreements among the results of the 3 years, with few genotype $\times$ year interactions. For example, the correlation coefficients among the 3 years ranged from 0.58 to $0.92(P<0.01)$ for the percent defoliation and from 0.65 to $0.89(P<0.01)$ for AUDPC (Table 2).

Greenhouse experiments. For each isolate, results from the two runs were similar and there was no significant genotype $\times$ run interaction. Therefore, data were pooled over runs and reanalyzed.

Isolate 126. Early blight lesions started to appear 2 to 3 days after inoculation. However, plants were evaluated once for percent defoliation 6 days after inoculation. There were significant $(P<0.01)$ differences among genotypes in percent 
defoliation. Similar to the field experiments, $L$. hirsutum accessions were generally the most resistant (Table 3). Cultivars New Yorker and Edkawy and breeding lines NC84173, UCT5, and NC24E were the least resistant, whereas the resistant lines 88B231, C1943, NCEBR-1, NCEBR5, NCEBR-6, and NC39E exhibited low to moderate resistance (Table 3 ).

Isolate 134 . The results were generally similar to those for isolate 126 (Table 3), and across genotypes, there was a significant correlation $(r=0.82, P<0.01$; Table 2) between percent defoliation incited by the two isolates. Furthermore, over genotypes, no significant difference was observed between the average percent defoliation incited by isolate $126(41.4 \%)$ and by isolate $134(41.3 \%)$ (Table 3$)$. However, ANOVA indicated the presence of a few genotype $\times$ isolate interactions $(P<0.05)$.

Growth chamber experiments with detached leaflets. Isolate 126. There were significant $(P<0.01)$ differences among genotypes in final lesion size (lesion radius) and final disease severity (Table 3). The lesion radius ranged from $4.6 \mathrm{~mm}$ for $\mathrm{NC} 24 \mathrm{E}$ to $15.2 \mathrm{~mm}$ for NC39E, with an average of $10.7 \mathrm{~mm}$. The final disease severity (percentage of leaflet infection) ranged from $22 \%$ for NC24E to $88 \%$ for $L$. pimpinellifolium accession LA722, with an average of $40 \%$. The rate of lesion expansion ranged from $0.59 \mathrm{~mm} /$ day for NC24E to $2.29 \mathrm{~mm} /$ day for $L$. hirsutum accession PI390661, with an average of 1.28 (Table $3)$.

Isolate 134. There were significant $(P<$ 0.01 ) differences among genotypes in final lesion radius and final disease severity (Table 3 ). The lesion radius ranged from $4.1 \mathrm{~mm}$ for $89 \mathrm{~B} 21$ to $14.0 \mathrm{~mm}$ for L. hirsutum accession LA1363, with an average of $8.7 \mathrm{~mm}$. The final disease severity ranged from $2.9 \%$ for NCEBR-2 to $78 \%$ for $L$. hirsutum accession LA407, with an average of $30 \%$. The rate of lesion expansion ranged from $0.25 \mathrm{~mm} /$ day for $L$. hirsutum accession LA1033 to 1.94 for $L$. hirsutum accession LA1363, with an average of 1.08 (Table 3 ).

Comparison between isolates 126 and 134. Overall, isolate 126 was more pathogenic than isolate 134 (Table 3). However, there were significant $(P<0.01)$ genotype $x$ isolate interactions (data not shown). For example, some genotypes that exhibited resistance to isolate 126 appeared susceptible to isolate 134 (e.g., LA2099), and vice versa (e.g., 89B21, LA1310, and NC39E) (Table 3). There were also some similarities in response to these isolates. For example, L. hirsutum accession LA407 and L. pimpinellifolium accession LA722 were among the most susceptible to both $A$. solani isolates. Furthermore, there were less agreements between responses to the two isolates based on the lesion radius ( $r=$ $0.27, P>0.05)$ and rate of lesion expansion $(r=0.10, P>0.05)$ than based on the final percent severity $(r=0.55, P<0.01)$ (Table 2).

Relationship among field, greenhouse, and detached-leaflet experiments. Relationships between field and greenhouse evaluations. There were significant $(P<$ $0.01)$ correlations between field and $\mathrm{GH}$ results, with correlation coefficients ranging from 0.64 to 0.92 for isolate 126 and from 0.49 to 0.72 for isolate 134 (Table 2). Furthermore, the correlation coefficients were generally larger for the field 1996 and 1998 data than for the 1997 data. The correlation coefficients were generally similar based on both percent defoliation and AUDPC (Table 2).

Relationships between field and detached-leaflet evaluations. There was gen- erally no relationship $(r=0.00$ to $0.37, P$ > 0.05 ) between field results (percent defoliation or AUDPC) and detached-leaflet results (Table 2 ).

Relationships between greenhouse and detached-leaflet evaluations. There was little or no correlation between GH and DL results. The correlation coefficients for $\mathrm{GH}$ evaluations for isolate 126 and DL were all nonsignificant (Table 2). However, GH evaluations for isolate 134 exhibited small, but significant $(P<0.05)$ correlations with some of the DL evaluations.

\section{DISCUSSION}

A major difficulty in breeding tomatoes for EB resistance has been the screening process. Field evaluation has been the principal procedure, and one that has resulted in reliable information. Field screening, however, has limitations, as it depends on the presence of proper environmental conditions such as humidity, temperature, and the pathogen inoculum. Furthermore, field screening can often be carried out only once a year. Such limitations would restrict breeding progress. For example, even though the selected field locations for this study were expected to be optimal for EB development and disease screening, dry conditions in 1997 resulted in a limited EB epidemic. A major goal of this study was to determine whether screening for EB resistance in tomato can be reliably conducted in the $\mathrm{GH}$ or in the growth chamber using detached leaflets.

Relationships among field, greenhouse, and detached-leaflet evaluations. Results from GH experiments were highly similar to those from the field, as judged by the significant correlations between $\mathrm{GH}$ and field data. In particular, strong correlations were observed between GH results and both field 1996 and field 1998 results

Table 2. Pearson correlation coefficients for various disease evaluation parameters obtained from the 29 genotypes infected with Alternaria solani

\begin{tabular}{|c|c|c|c|c|c|c|c|c|c|c|c|c|c|c|}
\hline & \multicolumn{6}{|c|}{ Field (Fld) } & \multicolumn{3}{|c|}{ Greenhouse (GH) } & \multicolumn{5}{|c|}{ Detached-leaflets (DL) } \\
\hline & $\begin{array}{c}\text { Def- } \\
96^{t}\end{array}$ & $\begin{array}{l}\text { Def- } \\
97\end{array}$ & $\begin{array}{c}\text { Def- } \\
98\end{array}$ & $\begin{array}{l}\text { AUDPC- } \\
\text { 96 }^{\mathbf{u}} \\
\end{array}$ & $\begin{array}{c}\text { AUDPC- } \\
97 \\
\end{array}$ & $\begin{array}{l}\text { AUDPC- } \\
98 \\
\end{array}$ & $\begin{array}{l}\text { Def- } \\
126^{v}\end{array}$ & $\begin{array}{l}\text { Def- } \\
134 \\
\end{array}$ & $\begin{array}{c}\text { Def- } \\
\text { M }\end{array}$ & $\begin{array}{l}\text { Rad- } \\
126^{w}\end{array}$ & $\begin{array}{l}\text { Rate- } \\
126^{x} \\
\end{array}$ & $\begin{array}{l}\text { Sev- } \\
126^{y}\end{array}$ & $\begin{array}{c}\text { Rad- } \\
134\end{array}$ & $\begin{array}{c}\text { Rate- } \\
134\end{array}$ \\
\hline Fld-Def-97 & $0.58^{* * z}$ & & & & & & & & & & & & & \\
\hline Fld-Def-98 & $0.92 * *$ & $0.66^{* *}$ & & & & & & & & & & & & \\
\hline Fld-AUDPC-96 & $0.99 * *$ & $0.66^{* *} *$ & $0.95^{* *}$ & & & & & & & & & & & \\
\hline Fld-AUDPC-97 & $0.56^{* *}$ & $0.99 * *$ & $0.66^{* *}$ & $0.65 * *$ & & & & & & & & & & \\
\hline Fld-AUDPC-98 & $0.84 * *$ & $0.77 * *$ & $0.98 * *$ & $0.89 * *$ & $0.77 * *$ & & & & & & & & & \\
\hline GH-Def-126 & $0.90 * *$ & $0.65^{* *}$ & $0.82 * *$ & $0.92 * *$ & $0.64 * *$ & $0.81 * *$ & & & & & & & & \\
\hline GH-Def-134 & $0.72 * *$ & $0.50 * *$ & $0.56 * *$ & $0.72 * *$ & $0.49 * *$ & $0.58 * *$ & $0.82 * *$ & & & & & & & \\
\hline GH-Def-M & $0.85^{* *}$ & $0.62 * *$ & $0.74 * *$ & $0.86^{* *}$ & $0.60 * *$ & $0.74 * *$ & $0.97 * *$ & $0.94 * *$ & & & & & & \\
\hline DL-Rad-126 & $0.35^{\mathrm{ns}}$ & $0.17^{\mathrm{ns}}$ & $0.25^{\mathrm{ns}}$ & $0.32^{\mathrm{ns}}$ & $0.17^{\mathrm{ns}}$ & $0.26^{\mathrm{ns}}$ & $0.21^{\mathrm{ns}}$ & $0.33^{\text {ns }}$ & $0.27^{\mathrm{ns}}$ & & & & & \\
\hline DL-Rate-126 & $0.16^{\mathrm{ns}}$ & $0.01^{\mathrm{ns}}$ & $-0.09^{\mathrm{ns}}$ & $0.09^{\mathrm{ns}}$ & $0.00^{\mathrm{ns}}$ & $-0.08^{\mathrm{ns}}$ & $-0.04^{\mathrm{ns}}$ & $0.14^{\mathrm{ns}}$ & $0.04^{\mathrm{ns}}$ & $0.73 * *$ & & & & \\
\hline DL-Sev-126 & $0.22^{\mathrm{ns}}$ & $0.17^{\mathrm{ns}}$ & $0.21^{\mathrm{ns}}$ & $0.18^{\mathrm{ns}}$ & $0.17^{\mathrm{ns}}$ & $0.23^{\mathrm{ns}}$ & $0.22^{\mathrm{ns}}$ & $0.45^{*}$ & $0.33^{\mathrm{ns}}$ & $0.69 * *$ & $0.62 * *$ & & & \\
\hline DL-Rad-134 & $0.21^{\mathrm{ns}}$ & $0.11^{\mathrm{ns}}$ & $0.05^{\mathrm{ns}}$ & $0.19^{\mathrm{ns}}$ & $0.11^{\mathrm{ns}}$ & $0.07^{\mathrm{ns}}$ & $0.17^{\mathrm{ns}}$ & $0.39 *$ & $0.28^{\mathrm{ns}}$ & $0.27^{\mathrm{ns}}$ & $0.12^{\mathrm{ns}}$ & $0.10^{\mathrm{ns}}$ & & \\
\hline DL-Rate-134 & $0.37^{\mathrm{ns}}$ & $0.19^{\mathrm{ns}}$ & $0.09^{\mathrm{ns}}$ & $0.34^{\mathrm{ns}}$ & $0.18^{\mathrm{ns}}$ & $0.11^{\mathrm{ns}}$ & $0.23^{\mathrm{ns}}$ & $0.41^{*}$ & $0.32^{\mathrm{ns}}$ & $0.27^{\mathrm{ns}}$ & $0.10^{\mathrm{ns}}$ & $0.03^{\mathrm{ns}}$ & $0.48 * *$ & \\
\hline DL-Sev-134 & $0.09^{\mathrm{ns}}$ & $0.04^{\mathrm{ns}}$ & $0.05^{\mathrm{ns}}$ & $0.06^{\mathrm{ns}}$ & $0.04^{\mathrm{ns}}$ & $0.09^{\text {ns }}$ & $0.14^{\mathrm{ns}}$ & $0.47 *$ & $0.29^{\mathrm{ns}}$ & $0.43 *$ & $0.40^{*}$ & $0.55 * *$ & $0.69 * *$ & $0.50 * *$ \\
\hline
\end{tabular}

${ }^{\mathrm{t}}$ Def-96 = final percentage defoliation in the field in year 1996.

u AUDPC-96 = area under disease progress curve in the field in year 1996.

${ }^{\mathrm{v}}$ Def-126 = final percentage defoliation in the greenhouse caused by A. solani isolate 126 .

${ }^{\mathrm{w}}$ Rad-126 = average final lesion radius caused by the infection by A. solani isolate 126 .

${ }^{\mathrm{x}}$ Rate-126 = average rate $(\mathrm{mm} / \mathrm{day})$ of lesion expansion caused by the infection by $A$. solani isolate 126 .

y Sev-126 = average final percentage disease severity at the detached-leaflet level caused by the infection by A. solani isolate 126.

$\mathrm{z} *$, ** Significant at $P<0.05$ and $P<0.01$, respectively; ns $=$ not significant at $P<0.05$. 
(Table 2). EB was most epidemic in 1996 when humidity was higher, there was more rainfall, and the field was closer to natural sources of A. solani inoculum compared with 1997 and 1998. Thus, the 1996 field was the most optimal among the 3 years for screening tomato plants for EB resistance. Interestingly, the $\mathrm{GH}$ results exhibited the highest correlations with the 1996 field results (Table 2). Such high correspondence between $\mathrm{GH}$ and field results indicates that EB screening can be effectively and reliably carried out in the $\mathrm{GH}$, provided proper conditions are prepared. Furthermore, because GH screening can be conducted during the late seedling stage, and there is no need to wait until later maturity stages, it can significantly speed up the breeding progress by allowing multiple cycles of screening and selection in 1 year. Moreover, greenhouse screening should be particularly useful when field screening is ineffective due to unsuitable environmental conditions and/or the copresence of other defoliating diseases (e.g., Septoria leaf spot).

Unlike GH screening, the DL evaluation was found to be ineffective for screening tomato germ plasm for EB resistance. There was little or no correlation between the different runs of DL evaluations, or between DL evaluations and either field or GH evaluations (Table 2). We conclude that DL evaluation is not a useful procedure for tomato screening for EB resistance. This is in contrast to an earlier report that this method was useful for screening of tomatoes for EB resistance (20). Caution should be taken when using DL assay alone for evaluation of tomatoes for EB resistance.

Relationships among different evaluation methods under field conditions.

Various methods have been used to evaluate plants for disease resistance under field conditions $(3,19,27)$. In the present study, both final percent defoliation and AUDPC were used to evaluate and compare tomato genotypes. In all 3 years, there were strong positive correlations $(r=0.98$ to $0.99, P<$ $0.01)$ between final percent defoliation and AUDPC (Table 2). Thus, when screening large-size populations, it may be sufficient to conduct only a single evaluation. However, the timing for such evaluation is critical, as too early or too late evaluation may result in misleading information, a problem that may not occur when conducting multiple-point evaluations and calculating AUDPC. Multipoint evaluation also allows analysis of additional variables (e.g., speed of an epidemic).

Response of tomato germ plasm to early blight infection. Most of the $L$. hirsutum accessions exhibited almost complete resistance to EB under the very disease epidemic conditions of the field and the GH. Of these, only accessions PI126445 (12) and PI390513 and PI390662 (25) were previously evaluated and reported as being EB resistant. Part of the resistance observed in the $L$. hirsutum accessions was most likely due to their indeterminate growth habit, late maturity, and low fruit to foliage ratio. However, the observation that at the end of the growing season, when these plants were bearing many flowers and fruits, few or no EB symptoms were seen even on the older leaves suggests the presence of genuine resistance in these accessions. Similar results were observed when $\mathrm{F}_{1}$ progeny of a cross between the $L$. hirsutum accession PI126445 and the susceptible breeding line

Table 3. Early blight disease rating of tomato germ plasm at the whole plant level (in greenhouse) and detached-leaflet level (in growth chamber)

\begin{tabular}{|c|c|c|c|c|c|c|c|c|c|c|c|c|}
\hline \multirow[b]{4}{*}{ Genotype } & \multirow[b]{4}{*}{$\begin{array}{c}\text { Lycopersicon } \\
\text { species }\end{array}$} & \multirow[b]{4}{*}{$\begin{array}{l}\text { Growth } \\
\text { habit }^{w}\end{array}$} & & & & \multicolumn{7}{|c|}{ Detached-leaflet experiments } \\
\hline & & & & & & \multicolumn{3}{|c|}{ Isolate 126} & \multicolumn{3}{|c|}{ Isolate 134} & \multirow{3}{*}{$\begin{array}{c}\text { Mean } \\
\text { severity } \\
(\%)\end{array}$} \\
\hline & & & \multicolumn{3}{|c|}{ GH exp. (defoliation \%) } & \multirow{2}{*}{$\begin{array}{l}\text { Lesion } \\
\text { radius } \\
(\mathbf{m m})^{\mathrm{x}}\end{array}$} & \multirow[b]{2}{*}{$\begin{array}{l}\text { Rate }( \pm \text { SD }) \\
(\mathbf{m m} / \text { day })^{\mathbf{y}}\end{array}$} & \multirow[b]{2}{*}{$\begin{array}{c}\text { Severity } \\
(\%)^{\mathrm{z}}\end{array}$} & \multirow{2}{*}{$\begin{array}{c}\begin{array}{c}\text { Lesion } \\
\text { radius } \\
(\mathbf{m m})\end{array} \\
\end{array}$} & \multirow[b]{2}{*}{$\begin{array}{c}\text { Rate }( \pm \text { SD }) \\
(\mathbf{m m} / \text { day })\end{array}$} & \multirow[b]{2}{*}{$\begin{array}{c}\text { Severity } \\
(\%)\end{array}$} & \\
\hline & & & $\begin{array}{c}\text { Isolate } \\
126 \\
\end{array}$ & $\begin{array}{c}\text { Isolate } \\
134 \\
\end{array}$ & Mean & & & & & & & \\
\hline New Yorker & L. esculentum & $\mathrm{D}$ & 71.5 & 57.5 & 64.5 & 9.8 & $1.09 \pm 0.25$ & 41.5 & 9.1 & $1.21 \pm 0.50$ & 31.4 & 36.4 \\
\hline NC84173 & L. esculentum & $\mathrm{D}$ & 70.1 & 56.8 & 63.5 & 12.7 & $1.32 \pm 0.54$ & 41.5 & 8.6 & $0.98 \pm 0.15$ & 22.5 & 32.0 \\
\hline UCT5 & L. esculentum & $\mathrm{D}$ & 68.2 & 68.0 & 68.1 & 11.7 & $1.14 \pm 0.66$ & 30.0 & 11.0 & $1.26 \pm 0.38$ & 44.0 & 37.0 \\
\hline Edkawy & L. esculentum & I & 73.7 & 62.4 & 68.0 & 13.2 & $1.57 \pm 0.48$ & 54.4 & 9.8 & $1.28 \pm 0.21$ & 37.1 & 45.8 \\
\hline PI120256 & L. esculentum & I & 52.7 & 58.0 & 55.3 & 14.2 & $1.50 \pm 0.31$ & 54.4 & 10.4 & $1.40 \pm 0.12$ & 42.9 & 48.6 \\
\hline PI174263 & L. esculentum & I & 50.8 & 57.7 & 54.3 & 14.7 & $1.79 \pm 0.34$ & 67.5 & 10.4 & $1.32 \pm 0.26$ & 45.0 & 56.2 \\
\hline Hawaii 7998 & L. esculentum & I & 40.3 & 37.4 & 38.9 & 12.8 & $1.53 \pm 0.76$ & 54.4 & 10.2 & $1.42 \pm 0.17$ & 35.7 & 45.1 \\
\hline $88 \mathrm{~B} 231$ & L. esculentum & $\mathrm{D}$ & 41.7 & 40.3 & 41.0 & 10.6 & $1.05 \pm 0.36$ & 38.1 & 8.2 & $1.01 \pm 0.66$ & 30.0 & 34.1 \\
\hline 89B21 (71B2) & L. esculentum & $\mathrm{D}$ & 56.2 & 34.2 & 45.2 & 9.7 & $1.01 \pm 0.58$ & 30.5 & 4.1 & $0.48 \pm 0.08$ & 9.2 & 19.8 \\
\hline C1943 & L. esculentum & $\mathrm{D}$ & 48.2 & 44.5 & 46.3 & 10.7 & $1.05 \pm 0.31$ & 30.0 & 10.1 & $1.13 \pm 0.30$ & 30.0 & 30.0 \\
\hline NCEBR-1 & L. esculentum & $\mathrm{D}$ & 48.0 & 41.7 & 44.9 & 8.6 & $0.86 \pm 0.24$ & 23.1 & 8.8 & $0.98 \pm 0.13$ & 34.3 & 28.7 \\
\hline NCEBR-2 & L. esculentum & $\mathrm{D}$ & 59.5 & 46.2 & 52.8 & 10.1 & $1.12 \pm 0.41$ & 31.2 & 10.1 & $1.27 \pm 0.07$ & 2.9 & 17.1 \\
\hline NCEBR-5 & L. esculentum & $\mathrm{D}$ & 43.3 & 38.9 & 41.1 & 10.6 & $1.19 \pm 0.57$ & 30.0 & 9.6 & $1.07 \pm 0.68$ & 31.4 & 30.7 \\
\hline NCEBR-6 & L. esculentum & $\mathrm{D}$ & 48.5 & 21.8 & 35.1 & 9.6 & $0.96 \pm 0.43$ & 24.4 & 7.0 & $0.73 \pm 0.31$ & 17.9 & 21.1 \\
\hline NC24E & L. esculentum & $\mathrm{D}$ & 68.3 & 63.3 & 65.8 & 4.6 & $0.59 \pm 0.17$ & 22.0 & 8.8 & $0.93 \pm 0.44$ & 19.3 & 20.6 \\
\hline NC39E & L. esculentum & $\mathrm{D}$ & 45.2 & 38.8 & 42.0 & 15.2 & $2.23 \pm 0.98$ & 70.0 & 8.5 & $0.93 \pm 0.10$ & 31.0 & 50.1 \\
\hline LA386 & L. hirsutum & I & 15.5 & 21.8 & 18.7 & 13.2 & $1.25 \pm 0.83$ & 48.6 & 7.6 & $1.27 \pm 0.52$ & 30.2 & 39.4 \\
\hline LA407 & L. hirsutum & I & 27.4 & 50.2 & 38.8 & 12.9 & $1.41 \pm 0.69$ & 62.8 & 11.9 & $1.07 \pm 0.30$ & 77.5 & 70.2 \\
\hline LA1033 & L. hirsutum & I & 9.0 & 22.5 & 15.7 & 10.5 & $1.37 \pm 1.02$ & 33.3 & 6.9 & $0.25 \pm 0.44$ & 12.5 & 22.9 \\
\hline LA1363 & L. hirsutum & I & 15.3 & 36.0 & 26.8 & 11.9 & $1.43 \pm 0.15$ & 26.7 & 14.0 & $1.94 \pm 1.19$ & 37.4 & 32.0 \\
\hline LA1393 & L. hirsutum & I & 17.1 & 29.3 & 23.2 & 9.1 & $1.66 \pm 0.64$ & 43.8 & 7.0 & $1.53 \pm 1.21$ & 41.5 & 42.6 \\
\hline LA1777 & L. hirsutum & I & 11.2 & 19.9 & 15.5 & 7.6 & $0.95 \pm 0.74$ & 23.9 & 4.6 & $1.66 \pm 2.47$ & 8.8 & 16.4 \\
\hline LA2099 & L. hirsutum & I & 10.4 & 12.9 & 11.6 & 5.3 & $0.72 \pm 0.54$ & 10.1 & 10.6 & $0.64 \pm 0.44$ & 20.4 & 15.2 \\
\hline PI126445 & L. hirsutum & I & 10.3 & 27.2 & 18.7 & 7.7 & $1.14 \pm 0.47$ & 20.7 & 5.2 & $0.72 \pm 0.50$ & 12.7 & 16.7 \\
\hline PI390513 & L. hirsutum & I & & & & 11.8 & $1.32 \pm 0.59$ & 11.3 & & - & - & - \\
\hline PI390661 & L. hirsutum & I & & & & 10.3 & $2.29 \pm 1.24$ & 55.0 & & - & - & - \\
\hline PI390662 & L. hirsutum & I & 15.9 & 26.3 & 21.2 & 10.5 & $1.20 \pm 0.77$ & 38.1 & 9.0 & $1.16 \pm 0.27$ & 40.1 & 39.1 \\
\hline LA722 & L. pimpinellifolium & I & 54.0 & 61.3 & 57.7 & 10.7 & $1.21 \pm 0.30$ & 87.5 & 8.5 & $1.03 \pm 0.14$ & 59.3 & 73.4 \\
\hline LA1310 & $\begin{array}{l}\text { L. esculentum } \\
\text { (var. cerasiforme) }\end{array}$ & I & 37.2 & 43.9 & 40.6 & 11.0 & $1.24 \pm 0.50$ & 53.8 & 5.0 & $0.58 \pm 0.21$ & 11.0 & 32.4 \\
\hline Average & & & 41.1 & 41.4 & 41.3 & 10.7 & $1.28 \pm 0.38$ & 40.0 & 8.7 & $1.08 \pm 0.37$ & 30.2 & 35.3 \\
\hline $\operatorname{LSD}(0.05)$ & & & 16.5 & 21.0 & 11.5 & 2.7 & & 15.1 & 2.6 & & 16.2 & \\
\hline
\end{tabular}

\footnotetext{
${ }^{\mathrm{w}} \mathrm{D}=$ determinate, $\mathrm{I}=$ indeterminate.

${ }^{x}$ Radius calculated as one-half of the average of the two perpendicular diameters of the lesion.

y Rate of lesion expansion calculated as the slope of the regression of lesion radius on time.

${ }^{\mathrm{z}}$ Percentage of leaflet area covered by early blight lesion.
} 
NC84173 were evaluated for EB resistance under field conditions (data not shown). The latter observation suggests that the resistance of PI126445 is heritable. The metabolic processes that condition this resistance are not well understood $(7,10,21,25)$. Possibly, these accessions have developed some inherent resistance mechanisms through morphological and/or physiological adaptations over time. This resistance should be valuable for the development of EB resistance in tomato, as it has been previously demonstrated for accession PI126445, from which several resistant breeding lines were derived $(12,13,15)$. It is, however, noteworthy that most of the L. hirsutum accessions exhibited less resistance at the DL level compared with the whole plant level in the field or in the GH. This could be due to the high concentration of $A$. solani spores applied to leaflets or because the resistance of these accessions expresses only at the whole plant level. The latter may be another reason for the inadequacy of the DL method for evaluating tomato germ plasm for EB resistance.

Most of the resistant breeding lines did not exhibit a resistance comparable to that in the L. hirsutum accessions from which the EB resistance was primarily derived. Part of this reduction in resistance could be due to various physiological stresses such as the high fruit to foliage ratio, earliness in maturity, and determinate growth habit imposed upon the cultivated tomato through breeding. Also, the high disease pressure under our experimental conditions in the field or in the greenhouse could have overcome the moderate horizontal resistance in these lines. However, two of the lines, NC24E and NC39E, exhibited considerable field resistance (Table 1), although they were comparatively later in maturity than other resistant lines. Of these, NC39E also exhibited significant resistance under the very disease-conductive conditions of the GH (Table 3). Thus, NC39E could be useful for developing tomato cultivars with improved EB resistance. Cultivar Hawaii 7998, which is known to be resistant to many other diseases of tomato (personal communications with several tomato breeders), exhibited low to moderate resistance to EB. Although the indeterminate growth habit of this cultivar had some effect on its apparent resistance, it consistently exhibited more resistance than other indeterminate $L$. esculentum genotypes such as Edkawy, PI174263, and PI120256. We speculate that Hawaii 7998 contains some diseasenonspecific resistance genes. The $L$. pimpinellifolium accession LA722 exhibited a low level of resistance under both field and GH conditions (Tables 1 and 3). However, recently we have identified several $L$. pimpinellifolium accessions with strong EB resistance. Because of its close genetic relationship with the cultivated tomato, the red-fruited wild species $L$. pimpinellifolium can be more useful as a gene resource for tomato resistance breeding than the green-fruited wild species $L$. hirsutum, which is only distantly related to the cultivated tomato.

Conclusions. Significant correlations were observed between $\mathrm{GH}$ and field screenings of tomato genotypes for EB resistance. Greenhouse evaluation was found to be useful for screening tomatoes for EB resistance, and thus, it may be employed to facilitate EB resistance breeding. In contrast, disease response at the detached-leaflet level did not concur with either field or GH resistance, and thus, it may not be a useful method for screening tomato plants for EB resistance. Limited EB resistance was observed in the cultivated species of tomato, whereas strong resistance detected in the tomato wild species $L$. hirsutum and a few resistant lines derived from it.

\section{ACKNOWLEDGMENTS}

We thank Professors Richard Craig, Paul Grun, and Mike Orzolek for reviewing this manuscript and making valuable comments and suggestions. This research was supported in part by the National Research Initiative Competitive Grants Program, U.S. Department of Agriculture (9735300-4685), the Agricultural Research Funds administered by the Pennsylvania Department of Agriculture (ME447275), the Pennsylvania Vegetable Marketing and Research Program, and College of Agricultural Sciences, the Pennsylvania State University. This is contribution 335 of the Department of Horticulture, the Pennsylvania State University.

\section{LITERATURE CITED}

1. Andrus, C. F., Reynard, G. B., Jorgensen, H., and Eades, J. 1942. Collar rot resistance in tomatoes. J. Agric. Res. 65:339-346.

2. Barksdale, T. H. 1969. Resistance of tomato seedling to early blight. Phytopathology 59:443-446.

3. Barksdale, T. H. 1971. Field evaluation for tomato early blight resistance. Plant Dis. Rep. 55:807-809.

4. Barksdale, T. H., and Stoner, A. K. 1973. Segregation for horizontal resistance to tomato early blight. Plant Dis. Rep. 57:964-965.

5. Barksdale, T. H., and Stoner, A. K. 1977. A study of the inheritance of tomato early blight. Plant Dis. Rep. 61:63-65.

6. Barratt, R. W., and Richards, M. C. 1944. Physiological maturity in relation to Alternari blight in the tomato. Phytopathology 34:997.

7. Brian, P. W., Curtis, P. J., Hemming, H. G., Jeffreys, E. G., Unwin, C. H., and Wright, J. M. 1949. Alternaric acid, a biologically active metabolic product of the fungus Alternaria solani. Nature 164:534.

8. Brock, R. D. 1950. A search for resistance to defoliation by Alternari solani in the genus Lycopersicon. J. Aust. Inst. Agric. Sci. 16:90-94.

9. Chen, Z. X., and Mutschler, M. A. 1988. Tolerance in tomato to early blight (Alternaria solani (Ell. and Martin) Sor.). Tomato Genetics Coop. Rep. 38:13-15.

10. Cotty, P. J., and Misaghi, I. J. 1984. Zinniol production by Alternaria species. Phytopathology 74:785-788.

11. Douglas, B. 1922. A new Alternaria spot of tomatoes in California. Phytopathology 12:146-148.

12. Gardner, R. G. 1984. Use of Lycopersicon hirsutum P.I. 126445 in breeding early blight resistant tomatoes. (Abstr.) HortScience 19:208.

13. Gardner, R. G. 1988. NC EBR-1 and NC EBR-2 early blight resistant tomato breeding lines. HortScience 23:779-781.

14. Gardner, R G. 1990. Greenhouse disease screen facilitates breeding resistance to tomato early blight. HortScience 25:222-223.

15. Gardner, R. G., and Shoemaker, P. B. 1999. 'Mountain Supreme' early blight resistant hybrid tomato and its parents, NC EBR-3 and NC EBR-4. HortScience 34:745-746.

16. Goth, R. W. 1997. A detached-leaf method to evaluate late blight resistance in potato and tomato. Am. Potato J. 74:347-352.

17. Horsfall, J. G., and Barratt, R. Q. 1945. An improved grading system for measuring plant diseases. (Abstr.) Phytopathology 35:655.

18. Jones, J. B., Jr. 1999. Tomato Plant Culture-In the Field, Greenhouse, and Home Garden. CRC Press, New York.

19. Kalloo, G., and Banerjee, M. K. 1993. Early blight resistance in Lycopersicon esculentum Mill. transferred from $L$. pimpinellifolium (L.) and $L$. hirsutum f. glabratum Mull. Gartenbauwissenschaft 58:238-240.

20. Locke, S. B. 1948. A method for measuring resistance to defoliation diseases in tomato and other Lycopersicon species. Phytopathology 38:937-942.

21. Maiero, M., Bean, G. A., and Ng, T. J. 1991. Toxin production by Alternaria solani and its related phytotoxicity to tomato breeding lines. Phytopathology 81:1030-1033.

22. Maiero, M., Ng, T. J., and Barksdale, T. H. 1989. Combining ability estimates for early blight resistance in tomato. J. Am. Soc. Hortic. Sci. 114:118-121.

23. Maiero, M., Ng, T. J., and Barksdale, T. H. 1990. Genetic resistance to early blight in tomato breeding lines. HortScience 25:344-346.

24. Maiero, M., Ng, T. J., and Barksdale, T. H. 1990. Inheritance of collar rot resistance in the tomato breeding lines C1943 and NC EBR-2. Phytopathology 80:1365-1368.

25. Martin, F. W., and Hepperly, P. 1987. Sources of resistance to early blight, Alternaria solani, and transfer to tomato, Lycopersicon esculentum. J. Agric. Univ. Puerto Rico 71:85-95.

26. Moore, W. D. 1942. Some factors affecting the infection of tomato seedlings by Alternaria solani. Phytopathology 32:399-403.

27. Nash, A. F., and Gardner, R. G. 1988. Tomato early blight resistance in a breeding line derived from Lycopersicon hirsutum PI 126445. Plant Dis. 72:206-209.

28. Nash, A. F., and Gardner, R. G. 1988. Heritability of tomato early blight resistance derived from Lycopersicon hirsutum P.I 126445. J. Am. Soc. Hortic. Sci. 113:264-268.

29. Poysa, V., and Tu, J. C. 1996. Response of cultivars and breeding lines of Lycopersicon spp. to Alternari solani. Can. Plant Dis. Surv. 76:5-8.

30. Reynard, G. B., and Andrus, C. F. 1945. Inheritance of resistance to the collar-rot phase of Alternaria solani on tomato. Phytopathology 35:25-36.

31. Rotem, J., and Reichert, I. 1964. Dew-a principal moisture factor enabling early blight epidemics in a semi-arid region of Israel. Plant Dis. Rep. 48:211-215.

32. Shoemaker, P. B., and Gardner, R. G. 1986. Resistance and fungicide application interval for tomato foliar disease. Biol. Cult. Tests 1:24.

33. Steel, R. G. D., and Torrie, J. H. 1980. Principles and Procedures of Statistics. 2nd ed. McGraw-Hill, New York.

34. Wellman, F. L. 1943. A technique to compare virulence of isolates of Alternaria solani on tomato leaflets. Phytopathology 33:698-706.

35. Yarwood, C. E. 1946. Detached leaf culture. Bot. Rev. 12:1-56. 